\title{
The Importance of Intercultural and Communicative Competences for Tourism Labour Market
}

\section{Zuzana Sándorová}

Department of Tourism, Constantine the Philosopher University in Nitra, Slovakia.

\begin{abstract}
The present paper is founded on two pillars. Firstly, it is one of the current trends in education worldwide, i.e. to connect theory and practice. Secondly, it is the need to be interculturally competent speakers of a foreign language in today's globalized world of massive migration flows and signs of increasing ethnocentrism. Based upon these two requirements, the ability to communicate in a FL effectively and interculturally appropriately in the tourism industry is a must, since being employed in whichever of its sectors means encountering other cultures on a daily basis. Therefore, the aim of the present study was to find out undergraduate tourism students' opinion on the importance of intercultural communicative competences for their future profession as well as their self-assessment in the given field. The findings of the research, which are to be compared to employers' needs, revealed that there is considerable difference between the respondents' views on the significance of the investigated issues and their self-esteem.
\end{abstract}

Keywords: intercultural communicative competences, competency development, tertiary education, undergraduate tourism students, questionnaire survey. 


\section{Introduction}

As stated in the Strategic framework - Education \& Training 2020 (European Commission, 2009), "in our increasingly globalised and knowledge-based economy, Europe is in need of a well-skilled workforce to compete in terms of productivity, quality, and innovation". Despite the mentioned objective, in Slovakia growing discrepancies can be detected between the demand of the labour market and the skills people acquire, what, consequently, might lead to unemployment. Therefore, "effective communication between the labour market and the education and training sector is vital” (ibid.).

The present paper is part of a research project whose aim is to find out to what extent the accredited 8.01.01 Tourism study programme develops students' competences with regard to the needs of their future profession. In addition, a further objective of the investigation is to make recommendations to optimize the content of the given study programme in correspondence with employers' needs. The data are collected through a three-phase questionnaire survey amongst the students of the 8.01.01 Tourism Bachelor's degree study programme, studying at Constantine the Philosopher University in Nitra in Slovakia, both before and after having completed their three-month compulsory traineeship. In addition, the results are also to be compared with the findings of the questionnaire survey carried out among the entrepreneurs of the tourism sector in Slovakia.

The 8.01.01 Tourism study programme at Constantin the Philosopher University in Nitra, Slovakia is offered by the Department of Tourism, at the Faculty of Central European Studies. The main objective of this three-year Bachelor's study programme is to provide preparation of competent experts in tourism, especially in the context of the multicultural and multinational regions of Central Europe. The study connects theoretical knowledge with practical training in the business sphere, mainly in the tourism sector, which enables students to use the acquired knowledge directly in practice. With regard to the mentioned focus on the multicultural and multinational character of the Central-European regions, special emphasis is put on language education, since in addition to world languages, such as English or German, undergraduates also have to learn one of the languages of the regions in question, i.e. Hungarian, Polish, or Czech.

Although the research project is focused on tourism students' overall competences, (from problem-solving and team-leading through managerial and interpersonal skills to revenue and yield management or controlling quality), the present study only deals with the aspects of intercultural and communicative competences.

As far as intercultural competence (IC) is concerned, according to the Common European Framework for Languages: Learning, Teaching, Assessment (Council of Europe, 200, p. 104) it is "the ability to bring the culture of origin and the foreign culture into relation with each other", as well as to be culturally sensitive and apply a range of strategies to establish and 
maintain contact with the members of the target community (Byram, 1997; Risager, 2006). In addition, FL learners must also be equipped with the ability to overcome stereotypes (Byram, 1991; Hidasi, 2004).

Jong (1996) defines communicative competence (CC) as the ability to use a foreign language effectively, which in addition to knowledge of vocabulary and grammar, also comprises the knowledge of foreign culture in terms of issues that should be avoided, what topics are considered safe or how to cope with misunderstandings that might occur during intercultural interactions. Similarly, Kachru and Nelson (1996, p. 90) also understand CC in terms of appropriateness, with regard to "all facets of language, including rate of speech and level or register of lexis", hence, the ability to recognize the different types of situations is equally important (Hall, 2002). According to Saville-Troike (1996, p. 362), CC, which consists of linguistic knowledge, interaction skills and cultural knowledge, can be "broadly defined as what a speaker needs to know to communicate appropriately within a particular speech community".

The importance of IC and CC has been verbalized by many intercultural scholars (e.g. Byram, 1991; Byram, 1997; Kramsch, 1998; Malota et al., 2013; Reynolds et al., 2004; Róka et al., 2009, etc.); however, it has probably been the most concisely formulated by Liu et al. (2011, p. 26), who claim that "only by competently interacting with others who are culturally different from us can our global village survive”. They also add that "intercultural skills do not come naturally; they have to be acquired through conscious learning”.

In order to develop CC, undergraduates of the 8.01.01 Tourism study programme at Constantine the Philosopher University in Nitra have been offered four courses throughout their three-year studies. English/German language 1 in the first and English/German language 2 in the second semester is provided in form of ninety-minute blocks once a week, during the twelve weeks of the semester. The syllabi are concerned with basic tourism terminology and relevant issues in the field. Similarly, students are offered a ninety-minute course of Business English/German 1 in the third semester once a week. The number of lessons is increased only in the fourth semester, since Business English/German 2 is provided once a week as a 180-minute block. Both courses of Business English/German deal with business and economy-related issues in a tourism-industry context.

As to the development of IC, students of the 8.01.01 Tourism Bachelor's study programme are not offered any courses on intercultural communication. Hence, students can foster their intercultural skills only within the mentioned language lessons or other vocational subjects, what to a great extent depends on teachers' willingness as well as on their competences in the given field. This fact raises the question whether the structure of the offered courses and the number of the lessons per week is appropriate and satisfactory with regard to the objective 
of the study programme, i.e. to provide well-prepared, competent experts for the tourism labour market.

Therefore, the aim of the present study was to investigate students' opinions on the relevance of the selected issues in terms of their future employment in the tourism industry, as well as their self-assessment in the field in question. The paper is divided into four main parts. The intorduction is followed by the research methodology, together with the research objectives and questions; in addition, the last parts contain the findings of the investigation and the conclusions.

\section{The method}

The main research aim was to learn about undergraduate tourism students' opinion on the importance of IC and CC for their future profession as well as about their self-esteem in the given field.

Based on the research objective, the following research questions were formulated:

1. What percentage of the respondents considers the following items to be very important and always necessary or highly important and often necessary: a.) CC in spoken communication, b.) CC in written communication , c.) intercultural competence?

2. What percentage of the respondents believes to be very well or completely prepared for the tourism labour market in terms of the following items: a.) CC in spoken communication, b.) CC in written communication, c.) intercultural competence?

With regard to the main aim, students' opinions were investigated through a questionnaire survey.

The sample consisted of 104 undergraduates of the 8.01.01 Tourism Bachelor's study programme, studying at the Department of Tourism, Faculty of Central European Studies, Constantine the Philosopher University in Nitra, Slovakia.

The questionnaire with 12 questions focused on the undergraduates' overall competences, (including their work experience and extracurricular activities). However, the present study only investigated two out of the twelve questions, as follows:

Question number 1: In your opinion to what extent are the following skills and competences important with regard to your future employment in the tourism sector? Please, indicate on a scale from 1 to 5 (1 - unimportant, completely unnecessary, 2 - important to a small extent, rather unnecessary, 3 - important to an average extent, rather necessary, 4 - highly important and often necessary, necessary, 5 - very important and always necessary). 
Question number 2: Self-assessment - What do you think how well you are prepared to use the given competences in your future profession? Please, indicate on a scale from 1 to 5 (1 I am not prepared at all; 2 - I am prepared only to a very small extent; 3 - I am only partially prepared; 4 - I am well prepared; 5 - I am completely prepared).

In addition, as already aforementioned, within both questions only three out of the thirty-two items, i.e. competences were investigated, as follows:

Item number 5: Intercultural competence

Item number 7: Communicative competence in written communication

Item number 9: Communicative competence in spoken communication.

\section{Results and discussion}

As it can be seen in Figure No 1, according to the students' views, CC in spoken communication is the most important one of all the three competences, for it is considered by $57.69 \%$ of the respondents as very important and always necessary and by $31.73 \%$ as highly important and often necessary, reaching together $89.42 \%$ agreement on the importance of this skill. 


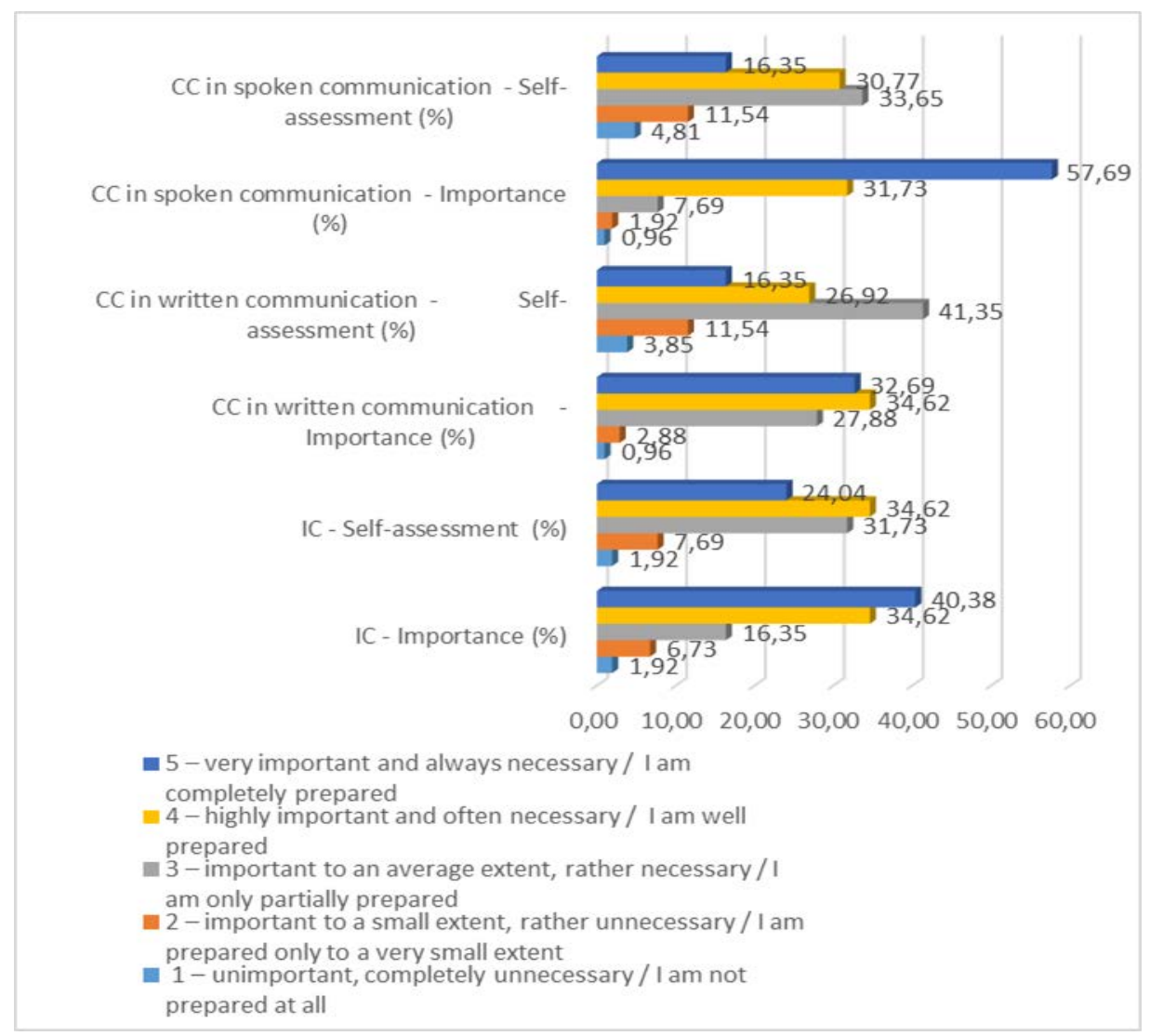

Figure 1: Students' opinion on the importance of CC and IC and their self-assessment

Furthermore, $7.69 \%$ of the students thought that it was important to an average extent and rather necessary; and, only according to $1.92 \%$ and $0.92 \%$ of the students it was important to a small extent, rather unnecessary or unimportant and completely unnecessary.

On the other hand, only $16.35 \%$ of the respondents thought that they were completely prepared and $33.77 \%$ considered to be well prepared to speak a foreign language effectively in their future jobs, what is $50.12 \%$ together. Moreover, $33.65 \%$ claimed that they were only partially prepared; in addition, $11.54 \%$ said that they were prepared only to a very small extent and $4.81 \%$ indicated that they were not prepared at all.

As far as the CC in written communication is concerned, it seems that it is considered the least important out of the three investigated items, since it was indicated by $32.69 \%$ of the respondents as very important and always necessary and by $34.62 \%$ as highly important and often necessary, that is $67.31 \%$ together. Furthermore, $27.88 \%$ of the students thought that it was important to an average extent and rather necessary; however, similarly to the ability 
to speak a WL effectively, only $2.88 \%$ and $0.96 \%$ considered this skill to be unimportant, completely unnecessary or important to a small extent, rather unnecessary.

In comparison with the undergraduates' self-assessment, $16.35 \%$ thought that they were completely prepared and $26.32 \%$ considered to be well prepared to use a foreign language effectively in written communication in their future job positions, reaching together $42.67 \%$ agreement on the level of preparedness. In addition, $41.35 \%$ claimed that they were partially prepared. However, $11.54 \%$ indicated that they were prepared only to a very small extent and $3.85 \%$ chose the option of not being prepared at all.

In terms of IC, it was perceived by $40.38 \%$ of the respondents as very important and always necessary and by $34.62 \%$ as highly important and often necessary, which together makes a $75 \%$ agreement on the necessity of this skill. In addition, even though $16.35 \%$ of the respondents thought that it was important to an average extent and rather necessary, according to $6.73 \%$ and $1.92 \%$ of the students, IC could be regarded as important to a small extent, rather unnecessary or even unimportant and completely unnecessary.

As to the students' self-assessment in the given field, $24.4 \%$ claimed that they were completely prepared and $34.62 \%$ indicated that they were well prepared to act interculturally appropriately in different situations in their future tourism positions, reaching together 59.02 $\%$ agreement on the level of preparedness. However, $31.73 \%$ of the respondents considered to be only partially prepared; in addition, $7.69 \%$ and $1.92 \%$ indicated that they were prepared only to a very small extent or not prepared at all.

\section{Conclusion}

In order to draw conclusions, firstly, the findings of the investigation will be summarised through giving answers to the research questions.

1. What percentage of the respondents considers the following items to be very important and always necessary or highly important and often necessary: a.) CC in spoken communication, b.) CC in written communication, c.) intercultural competence?

The examined items were considered to be very important and always necessary or highly important and often necessary by:

a.) CC in spoken communication : $89.42 \%$

b.) CC in written communication: $67.31 \%$

c.) intercultural competence: $75 \%$ of the respondents. 
2. What percentage of the respondents believes to be very well or completely prepared for the tourism labour market in terms of the following items: a.) CC in spoken communication, b.) CC in written communication, c.) intercultural competence?

$47.12 \%$ of the respondents believed that they were very well or completely prepared for the tourism labour market in terms of CC in spoken communication, while with regard to CC in written communication it was $43.27 \%$. In addition, in relation to IC $54.66 \%$ of the respondents thought they were very well or completely prepared for their future profession.

In the light of the results, several conclusions can be drawn. Firstly, it is the considerable difference between the importance of the investigated items and respondents' selfassessment, especially in terms of CC in spoken communication (high importance: $89.42 \%$ - low self-esteem: $47.12 \%$ ), but also in case of the other two investigated issues (written communication: importance - $67.31 \%$, self-assessment - $43.27 \%$; intercultural competence: importance - $75 \%$, self-assessment - $54.66 \%$ ). Here, the question arises as to whether the findings reflect undergraduates' lack of self-confidence or their lack of knowledge. It seems that the answer could only be given after further investigation in the field; and, a holistic view of the situation may be captured through the comparison of the present findings with the employers' responds as well as with the students' opinions after having completed their traineeship. In addition, to shed light on the reasons that lie behind the findings, it might be advisable to test undergraduates' knowledge and competences in the examined fields, i.e. their IC and CC. Yet, apparently, the data show that there is a need to support the development of the examined competences and to increase students' self-confidence in the field. Hence, in order to give them more opportunities to practice the foreign language both in written and spoken communication, it would be worth considering that the number of FL lessons per semester be increased. In addition, integrating new courses in the 8.01.01 Tourism study programme, such as Intercultural communication would undoubtedly contribute to the development of undergraduates’ intercultural skills.

\section{References}

Byram, M. (1991).Young people's perception of other cultures: the role of foreign language teaching. Mediating Languages and Cultures: Towards an Intercultural Theory of Foreign Language Education. Clevedon: Multilingual Matters, 103-119.

Byram, M. (1997). Teaching and Assessing Intercultural Communicative Competence. Clevedon: Multilingual Matters.

Council of Europe. (2001). A Common European Framework of Reference for Language Learning, Teaching, Assessment. [Electronic version]. Retrieved from $<$ http://www.coe.int/t/dg4/linguistic/Source/Framework_EN.pdf>. 
European Commission. (2009). Strategic framework - Education \& Training 2020. [Electronic version]. Retrieved from < http://ec.europa.eu/education/policy/strategicframework_en>.

Hall, J.K. (2002). Teaching and Researching Language and Culture. Harlow: Pearson Education Limited.

Hidasi, J. (2004). Interkulturális kommunikáció. Budapest: Scolar Kiadó.

Jong, W. (1996). Open frontiers: Teaching English in an intercultural context. Oxford: Reed Educational and Professional Publishing Ltd., 1996.

Kachru, B.B. \& Nelson, C.L. (1996). World Englishes. Sociolinguistics and Language Teaching. Cambridge: Cambridge University Press, 1996. pp. 71 -102.

Kramsch, C. (1998). Language and Culture. Oxford: Oxford University Press, 1998. ISBN: 97800194372145

Liu, S. et al. (2011). Introducing Intercultural Communication. Global Cultures and Contexts. London: SAGE.

Malota, E. \& Ariel, M. (2013). Kultúrák találkozása. Budapest: Alinea Kiadó.

Reynolds, S. \& Valentine, D. (2004). Guide to cross-cultural communication. New Jersey: Pearson Education, Inc.

Risager, K. (2006). Language and culture: Global Flows and Local Complexity. Clevedon: Multilingual Matters LTD.

Róka, J. \& Hochel, S. (2009). Interkulturális és nemzetközi kommunikáció a globalizálódó világban. Budapest: Budapesti Kommunikációs és Üzleti Főiskola.

Saville-Troike, M. (1996). The ethnography of communication. Sociolinguistics and Language Teaching. Cambridge: Cambridge University Press, 1996. pp. 351-382. 